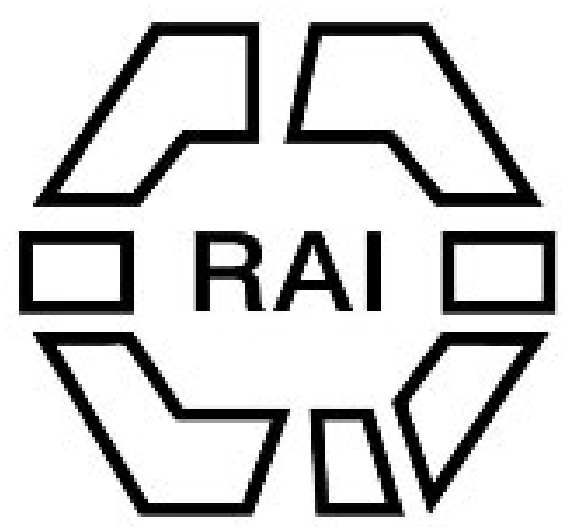

Notes on the History of Vumba, East Africa

Author(s): A. C. Hollis

Source: The Tournal of the Anthropological Institute of Great Britain and Ireland, Vol. 30 (1900), pp. 275-297

Published by: Royal Anthropological Institute of Great Britain and Ireland

Stable URL: http://www.jstor.org/stable/2842633

Accessed: 16/06/2014 14:58

Your use of the JSTOR archive indicates your acceptance of the Terms \& Conditions of Use, available at http://www.jstor.org/page/info/about/policies/terms.jsp

JSTOR is a not-for-profit service that helps scholars, researchers, and students discover, use, and build upon a wide range of content in a trusted digital archive. We use information technology and tools to increase productivity and facilitate new forms of scholarship. For more information about JSTOR, please contact support@jstor.org. 


\title{
NOTES ON THE HISTORY OF VUMBA, EAST AFRICA.
}

\author{
By A. C. Holisis.
}

\section{[W ith Plates XXVII, XXVIII, XXIX.]}

The Mohammedans, as is well known, displayed, for some centuries after the death of their great prophet, a remarkable activity in attempting to subjugate and, at the same time, to evangelise the world. Thus, the Moors predominater in northern Africa and extended their conquests to Spain and to other countries in southern Europe; the Saracens drove the Byzantine emperors from their Asiatic dominions and made themselves masters of the places held sacred by the early Christian Church; and the Arabs and Persians emigrated to and colonised various parts of India and Africa.

A few of the latter people, coming from the plains of Shirazi, settled, about the time King John ascended the throne of England, near the mouth of a river on the mainland of the east coast of Africa, almost opposite Pemba (a large island north of Zanzibar), and some fifty miles south of Mombasa, the capital of the East Africa Protectorate and the terminus of the Uganda Railway. This river, the mouth of which divides the British and German spheres of influence, is known by the name of Umba, whilst the district watered by its delta is called Vumba. ${ }^{1}$

To the present day, on the banks of the Mchamalale ${ }^{2}$ stream (one of the arms of the Umba river), in an almost impenetrable jungle between Vanga ${ }^{3}$ and Jasin, 4 are to be seen the remains of what formerly must have been a large city. This

1 The Umba river rises near Mlalo in the Usambara hills, a range running at right angles to the coast from Tanga (a town thirty miles south of the Anglo-German frontier) towards Kilima Njaro, the highest mountain in Africa. The name is believed to be taken from the Kiswahili, or native word, $M a u m b a$, meaning sea-urchins, which are found in large quantities on its banks, whilst Vumba is thought to be a corruption of Kuumba viungu, to make pots, the soil being particularly adapted to pottery work of all kinds, large quantities of earthen utensils being shipped from the neighbouring ports to Zanzibar, Pemba and Mombasa. The Portuguese, it would seem, originally called the district Uumba, i.e., the country of the Umba; it is, therefore, possible that both Vumba and Umba are derived from the same root.

2 Mchamalale is commonly, but erroneously, written Msemelale.

3 Vanga is sometimes incorrectly spelt Wanga (vide also Le Roi : Le Kilimanjaro). This is the most southerly town in British territory. Kuvanga, in Kiswahili, is the same as Kupanga, and means, literally, to pile up (loads), hence, to rest or stay. The word is believed to refer to the fertility of the soil. Of this town more anon.

4 Jasin is a small town in German East Africa, three miles from Vanga. 
was Vumba Kuu, or Great Vumba. Vumba Ndogo, or Little Vumba, is the name of the Wasin'-Kigomeni²-Vanga district.

When, in 1895, Sheikh Mbaruk bin Rashid el-Khelani-el-Mazrui of Gasi” joined forces with a distant cousin, Sheikh Mubarak bin Rashid el-Mazrui of Takaungu, ${ }^{4}$ and rebelled against the British Government, which had lately superseded the Imperial British East Africa Company, ${ }^{5}$ one of the first aggressive acts on his part was to plunder and sack Vanga,${ }^{6}$ whilst, shortly afterwards, our troops burnt Ormuz, ${ }^{7}$ the chief village in the Pongwe district. ${ }^{8}$

With the destruction of these two towns many priceless books and documents belonging to the Arab settlers were lost, amongst them the Chronicles of Vumba Kuu. These, I am told, were contained in a single manuscript volume and gave a list of the names of the chieftains of this place together with the dates of events which happened during their reigns, from circa 600 to 1100 A.H., or A.D. 1204 to $1688 .^{9}$

In order, therefore, to save, to a certain extent, the history of the country, known to but a few of a generation rapidly passing away, I have written down the story as related to me by the aged Shereef Abubakari bin ${ }^{10}$ Kasim bin Diwan Kikambala el-Masela-ba-Alaui, ${ }^{11}$ by his brother, Shereef Alaui bin Kasim bin Diwan Kikambala el-Masela-ba-Alaui, by the Liwali of Vanga, Abubakari bin Ali elHasraji-el-ba-Urii (a descendant of Diwan Ruga and a cousin of Diwan Marithia), by Shereef Abubakari bin Diwan Kilimia el-Jadid, by Buhuri bin Nyale bin Mwalimu Mwahathi el-Bajun, the chief elder of the Wasegeju of Pongwe, and by Kalamu Mwacholozi, the Kubo or Chief of the Wadigo, ${ }^{12}$ all of whom are well versed in the traditions and folk-lore of the land.

1 Wasin (frequently written Wassein) is an island off the British coast not far from Vanga. For a description, vide page 284.

2 Kigomeni is a small fishing village in German territory, near Jasin.

3 Gasi, commonly, but erroneously, spelt Gazi, is situated half-way between Mombasa and Vanga. From 1837 to 1895, it was the seat of the elder or el-Khelani branch of the Mazrui (or, to use the correct Arabic form, Mazaran) chieftains.

4 Takaungu, the seat of the younger branch of the Mazrui, is a town some thirty miles north of Mombasa.

- Vide Blue-Book No. 6 (1896). Correspondence concerning the recent rebellion in East Africa.

${ }^{6}$ Ibid., p. 12.

' 1bid., p. 52.

8 Pongwe is the name of a part of Vumba Ndogo. The meaning of the word, which is pronounced by the natives P'ongwe, is unknown.

9 The Mohammedans reckon from the Hijra or era of the flight, which took place on Eriday, July 16th, A.D. 622. The year contains $354 \frac{11}{30}$ days.-The Indian Calendar.

${ }_{10} B$ in (Arabic $i b n$ ) means son of ; binti, daughter of.

"Alaui is a contraction of the Arabic Alui.

${ }_{12}$ The Wadigo and Wasegeju are the principal native tribes inhabiting the Vumba district. According to tradition, the Wadigo, one of the numerous allied clans known collectively as the Wanyika, or desert people, who fringe this part of the African coast, were already settled in the country when the first of the Sultans of Vumba Kuu was chosen. They are believed to have come from Digi and Kirau in Shungwaya, the rative name for the plains lying on the left 
When I knew their story, I set to work to try and fincl the lost volume. In this I was unsuccessful, but, after some search, a manuscript book-a treatise on religious matters-was discovered at Vanga. This, as the author ${ }^{1}$ informs the reader at the end of his essay, was finished at Pate," after mid-day prayer, on the 7 th day of the third month, 1133 A.H. (1721 A.D.). Down the margins of the pages of this book are jotted the dates of various events concerning the ba-Alaui, min-Ali-Sheikh-Abubakari-bin-Salim, el-Jaclid and el-ba-Urii families, together with some pedigrees, which verify and corroborate the statements made by my informants. One other discovery was made, viz.:-a list of the nicknames of all the chieftains of Vumba Kuu in the handwriting of the last of the Diwans who died in 1897 .

As will be seen later, I also refer, at times, to other books and documents, one especially, called The Story of Mombasa, ${ }^{3}$ by an unknown author, having been of great service to me. For the allusions made to the Portuguese state papers $1 \mathrm{am}$ indebted to Mr. Justus Strandes, the author of Die Portugiesenzeit von Ostafrika (Berlin, 1899).

The chieftains of Vumba Kuu were considered as important as most of the rulers on the coast. Their successor of to-day, the Diwan ${ }^{5}$ or Pontiff of Vumba Ndlogo, is merely the head of two or three large clans of Shereefs, i.e., descendants

lank of the Tana, a river some two hundred miles north of Mombasa. The Wasegeju, or, as they were formerly called, the Wakilio, claim descent from the Somali. For an account of the ilrival of these people, vide page 281. The name, Wasegeju, is derived from $K^{\prime}$ usega, to draw up the clothes, and Juu, high. This name was given them, owing to their wearing the skins round their loins higher than usual. The aboriginal inhabitants of this country are thought to have been the Wasi, who were divided into three groups, the Wamaraka, the Wamaumba and the Watwa. A few Wamaraka are now settled at Ada, a town some fifty miles west of Gasi, the Wamaumba live with the Wachonyi, one of the Wanyika tribes, some thirty miles north of Mombasa, whilst the Watwa are to be found in small numbers round Lamu, a wellknown town not far from the mouth of the Tana river:

1 The author was one Abubakarj bin el-Fakihi Mwalimu Saleh bin el-Fakihi Mrbwana Kombo bin el-Fakihi Haji bin Saburi bin el-Fakihi Suhele bin Sheikh el-Marız-el-ba-Urii.

: Pate is a town of great antiquity on Siu Island near the mouth of the Tana river. It is sometimes erroneously written Patta or Pattah, and Siu is often wrongly spelt Siwi.

"In this story, written in Arabic, the ammals of Mombasa are recorded from the time of the coming of the Portuguese till the death, in 1856, of Seyyid Said, the first of the Albusaidi Sultans of Zanzibar. Although not given at such length as in Owen's Nurrotive of royages to explore the shores of Africa, Arabia and Aladagascar, in Kraftis Reisen im Alstande, or in

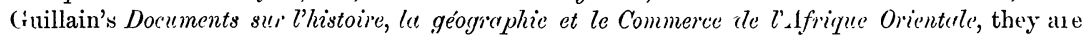
interestingly written.

4 The chieftains of Vumba Kuu were called 1/ucance Chambi until circu 950 A.II. (15+4 A.D.), when the name was changed to Mwana Chambi Chandi. About 1112 A.H. (1700 A.D.) it was again altered to Divan. The other principal chieftains on the coast were those of Pate, Saadani or Utondwe (the Otondo of the Portuguese), Zanzibar or Unguja, and Kilwa. The name given to those of Pate was Mrvenyi Mrui, and, at a later date, Fumo, to those of Saadani, Mwi Kambre, and to those of Zanzibar and Kilwa, Mlfalme. The less important chiefs of Tanga were called Alicenyi Chetmbi.

- The name Dizan was bor'owed from Pate. It means in Arabic reigning house. In Indian phraseology the East India Company was called Dizcen. 
of the Prophet's race. He is, however, held in high esteem by these people, and is much revered and almost worshipped by the ignorant Wacligo and Wasegreju.

The territory and jurisdiction of the Sultans of Vumba ranged, in olden times, from Mawe mawili, two rocks off Kwale, some ten miles north of Tanga, German East Africa, to Likoni, the south side of Port Kilindini, near Mombasa, and inland, from the Usambara hills, in the south, to what is now the Duruma country, west of Mombasa, in the north.

Although these chieftains acknowledged the Portuguese, and after the final withdrawal of the Portuguese from Mombasa in 1729 A.D., ${ }^{1}$ the Mazrui governors of that town as their over-lords, yet they were practically independent until 1253 A.H. (1837 A.D.), ${ }^{2}$ when Mombasa was captured by the Albusaidi prince, Said bin Sultan, and the hereditary governor, Abdullah bin Hamis, was obliged to settle at Gasi. From this time dates the decline of their power. The Diwans of the present day, however, still receive many and often valuable gifts from the superstitious natives and others in exchange for charms. They also retain an ancient prerogative of becoming the owner of any slave, who, wishing to change masters, goes through the form of beating three times on the clrum, which, for this jurpose, stands outside the royal residence.

The chief qualification of a Diwan is to be a Shereef, descended, either in the male or female line, from the first Shereef Sultan of Vumba, Seyyid Abubakari bin Sheikh bin Abubakari el-Masela-ba-Alaui, otherwise called Diwan Ruga, who reigned from circa 1112 A.H. (1700 A.D.) till his death in 1155 A.H. (1742 А.D.). The only other qualifications necessary are that he be rich and that certain ancient ctustoms be allered to and rites performed before his election.

These are as follows:- In the first place, the candidate must marry the Jaughter of a Shereef or an Arab. This marriage is called arusi ya ada, ${ }^{3}$ and the bridegroom himself receives the title of muole, which is a promotion from the ranks of the rijanct. ${ }^{4}$ The fee referred to in this marriage ceremony means a great feast to all and sundry who wish to partake of it. If oxen are slaughtered, the marriage is called ar'usi yu ng'ombe, ${ }^{\circ}$ and the bridegroom receives more honour than at an arusi ya adu.

Should the bridegroom give a second feast to all his youthful friends, he is 1)romoted another grade and is called mten $i,{ }^{6}$ in which case no kijana may sil at iable with him. ${ }^{7}$

1 Portuguese State papers. Bibliotheca Nacional de Lisboa. Codice Manuscripto, No. 465.

2 The Story of Mombasa.

s Literally marriage of the fee, meaning a marriage for which a fee or customary present is paid,

${ }^{4}$ Plural of kijana, an unmarried youth.

${ }^{5}$ Literally marriage of the ox.

- Mtenzi wa kukirimu wat'u means one who produces various kinds of food at a banquet. Vide Krapf's Swahili-English Dictionary, page 254.

7 A man who marries but does not give the customary feast is called mondo. He is not at all respected and is bound to do the bidding of a mwole or mtenzi without nurmur or complaint. If a man has once arrived at the rank of mtenai, he can demand an invitation to any feast given in his natal or adopted town. 
Alter the marriage ceremony a certain period elapses before the candidate is called upon to prepare another feast. This occurs if his wife gives birth to in son.

At the next function which takes place, all the living descendants of Diwau liuga and the members of the houses Ba-Amiri and Mwenyi Chandi ${ }^{1}$ are called together, and at a great feast, at which they are given presents of money and clothes, the name of the canclidate is sulmitted to them for approval. If they are satisfied with their presents and with the candidate himself, the latter is formally invested with the vundu. ${ }^{2}$ He has now the right to wear wooden sandals instead of leather ones and is styled Diwoun. Messengers are then sent to the Molindzano clan of the Wadigo and to the Mwakamathi clan of the Wasegejus to request the pleasure of the company of their chiefs at a snall feast to be given in their honour. During the course of this feast the chiefs are informed of the election of the Diwan. They are further told that the enthronement will take place on a certain day at Vumba Kuu.

Other gifts have to be sent to the elder's of Mbayayi, ${ }^{4}$ Kirui, ${ }^{4}$ Muso, ${ }^{4}$ Mkumbi, ${ }^{4}$ Manza, ${ }^{4}$ Alene $^{5}$ and Funzi, ${ }^{6}$ to the representatives of the twelve towns or tribes of Mombasia and Kilindini ${ }^{7}$ and, until lately, to the reigning chief of the Mazrui and to the Albusaidi Sultans of Zanzibar.

On the day appointed for the enthronement, the Diwan proceeds to Vumba Kuu, a road having been previously cut through the thick, tangled wood. He is led by the members of the Ba-Amili and Mvenyi Chandi families (these people being the only persons permitted to enter the sacred precincts of the ruined city) to a small pile of stones, all that is left of what was once the grave of Mwana Chambi Chandi Ivor, the most powerful of the Sultans of Vumba. ${ }^{s}$ Here his feet are washed and he is crowned, i.e., a worked skull-cap is placed on his head round which a turban is tied. ${ }^{\circ}$ He then tells the senior member of the Ba-Amiri family present, who has had the honour of crowning him, what name he wishes to be

1 The chieftains of Vumba Kuu are believed to have all belonged to the Ba-Amiri or Mwenyi Chandi families.

"A silver chain worn above the right knee.

" Like all other native tribes in this part of Afriea, the Wadigo and Wasegreju are divided into clans, which clans are often subdivided into families.

1 Towns in German East Africa between Tanga and the Anglo-Gernun frontier.

- A town on the Pongwe creek. The inhabitants are called Wamwiyuni.

"A town on the bay of Funzi. The inhabitants are called Wakifundi.

- The Waswahili or natives of Mombasa and Kilindini are divided into twelve tuwus or tribes, viz. :-Mombasa (or Mvita), Mtwapa (or Mtwafi), Kilifi, Pate, Shaka, Paza, Akatwa (or somali), Gunya (or Bajun) and Junda (or Jomvu), Kilindini, Tangana and Changanwe.

8 I am informed that this grave, together with several others, was broken down by the employés of the German East Africa Company in 1896, in order that the stones might be used for building purposes at Jasin, one of their stations on the frontier. The natives say that bad luck will always follow the occupants of the house built from the stones of Vumba Kuu. A stune bearing an inscription, which was taken from these ruins, was sent by a former Governor of German East Africi, Major von Wissmamn, to one of the Berlin museunis.

"This is called kinpiga kilemba, to tie the turban. 
called, ${ }^{1}$ after which he is carried on a native bedstead, shaded by a large umbrella, to a place not far distant, where a great feast has been prepared, and where hundreds of expectant people are now assembled. The head of the Ba-Amiri next informs the chiefs of the Wadigo and Wasegeju that their Sultan has been crowned. These two men, in their turn, impart the news to all present, and, seizing a spear, each swears that he and his people will uphold their lord and master' and defend him from all enemies. The great feast, called Mshomara, is then commenced, and two thousand ells of cloth (worth about two thousand rupees) are given to the Wadigo and Wasegeju elder's. After the feasting has been kept up for some time, all the parties indulge in dancing to the accompaniment of the Sultan's musical instruments. These consist of two or three large drums, known as ngomc kut and gomct, several smaller ones, a long horn or siwa and two pairs of matuwazi or cymbals. After the dance the Sultan is carried home on the bedstead.

Wherever he goes he is now attended by slaves carrying the horn, a chair and the umbrella. ${ }^{2}$

If the Diwan's wife gave birth to a son, one more feast has still to take place. This follows shortly after the coronation festivities and is called Kumbi la ada, the feast of circumcision.

On the death of a Diwan there is a general mourning for forty days. During this period no Arab, Mswahili or native of Vumba may use more than one cloth to cover himself with; nobody may shave, nor may a cap or turban be worn. The house is watched from the outside by men, whilst the rooms are guarded by women. After fourteen days have elapsed, a great feast is given, and the Wadigo -especially the Birini clan-are permitted to take anything they like from the neighbouring plantations. As long as the feast lasts, a certain number of Wakifundi ${ }^{g}$ have to stand at the door of the house, and, as a sign that they are a conquered race, they may not complain if rice or other food is thruwn or dropped on them.

But one more custom is worthy of mention. An Arab or native of Vumba when speaking to his sultan has to uncover and remain thus until he receives permission to again wear his cap and turban. ${ }^{*}$ The Diwan is always addressed as Mrvenyi (Lord).

The first Sultan or Mwana Chambi of Vumba Kuu was nicknamed Zumbura. This, in the Kidigos dialect, means to find some thing or some place which is hidden, and is supposed to refer to the discovery of the Vumba

1 As will be seen later on, the Sultans all had nicknames. These nicknames they gave themselves at this point in the ceremony.

2 To the present day no native of Vumba, be he Mohammedan or heathen, may use an umbrella, except a crowned Diwan.

$\therefore$ Inte, p. 279 , note 6 ; also p. 282, note 7 .

4 This custom is all the more remarkable as it is otherwise considered, here as elsewhere, a mark of disrespect to uncover.

- The language of the Wadigo is called Kidligo; that of the Wasegeju, Kisegeju. 
country. He is believed to have been enthroned cirece 600 A.II. (1204 A.D.), and was buried, as were the six following chieftains, at Vumba Kuu.

Zumbura was succeeded by Marikuona. This word is believed to mean Ku once Mali, to find wealth.

The third Sultan was named Kinena (mons veneris). This is supposed to refer to his great strength.

Kinena was succeeded by Hundekun. Huncle, in the Kidigo dialect, means some thing, the name of which is unknown, and $K u$ is an adjective meaningr great. The signification is, therefore, some great thing, the name of which is unknown.

After Hundekuu came Mabric. This word means stalks of Indian corn or millet, and the chieftain who gave himself this name is believed to have wished to convey the idea that, as during the harvest season, he would not only be content to gather in the corn but would even look after the stubble in the fields, so he would see to the wants of the least of his people.

His successor was Niomvi. This is the name of a small bird which lives in the rice fields.

The seventh Sultan of Vumba Kuu was Mwenyi Chandi ${ }^{1}$ bin Sheihh. His father, Sheikh, who was a scion of a Mombasa family and hailed from the portion of that town known formerly by the name of Saalani, married a daughter of Mwana Chambi Niomvi. He did not change his name but was called Mwana Chambi Chandi. He lived to a great age and ruled well. After his death, the Sultans of Vumba were styled Mwana Chambi Chandi instead of Mwana Chambi, as heretofore.

Neither the name nor the real nickname of the next Sultan have been handed down to posterity. He is now known as Mwanc Chambi Chandi Mvenda nu Wagalla, i.e., the chieftain who went to the Galla. At this time the Galla, a warlike tribe from north of the Tana river, are said to have overrun the whole country, and one dayiwhilst the Sultan of Vumba Kuu was on his way to Gonja, a small town on the Umba river not far distant, he encountered a band of these savages. The Mwana Chambi Chandi himself and all his followers were slain. ${ }^{2}$

After a longer interregnum than usual, a successor was eventually chosen in the person of Mwana Chambi Chandi Lvor. This is not believed to have been the Sultan's real nickuame, but is probably a name given him by a tribe of people called the Wakilio, who, having been driven from their own lands, were granted permission by the chieftain of Vumba to settle in his territory. In the dialect of these people, who, as has been already stated, are now known by the name of

${ }^{1}$ Chandi, in Kishwahili, is the old form for Mjumbe, an ambassador ol' messenger.

2 In 1589 Mombasa was attacked by some 15,000 natives, called by the Portuguese historian Fr. Joâs dos Santos Zimbas, and by P. Pierre du Jarrie Imbies. These people came from south of the Zambesi river and on their march north devastated the town of Kilwa massacring 3,000 of the inhabitants (Strundes, p. 153). It is probable that the Vumbar chieftain was killed by these savages and not by the Galla. 
Wasegeju, ${ }^{1}$ Ivor signifies an ivory ring which is worn round the right arm above the ellow.

For many years past there had been great friction between the people of Vumba Kuu and the inhabitants of the towns Mbayaji, ${ }^{2}$ Muso, ${ }^{2}$ Kirui, ${ }^{2}$ Mkumli, ${ }^{2}$ Manjauli, ${ }^{3}$ Mwiyuni, ${ }^{4}$ Mdragoni ${ }^{5}$ and Kifundi, ${ }^{6}$ who, descended as they were from the early Shirazi or Wadaburi settler's from Persia, refused to acknowledge the Sultans of Vumba Kuu as their over-lords.

Mwana Chambi Chandi Ivor, therefore, eagerly cullected together the Wakilio and turned them into soldiers. By their help and by the assistance of the friendly Wadigo, he managed to vancuish the inhabitants of the eight towns mentioned above. As a sign of their defeat, these people were forbidden, for ever, to wear either sandals or turbans, to use umbrellas, to allow their women to veil their faces, to have solid wooden doors to their houses or to possess any other drum than that known as the "t'ut'u," which is so small that it can only be beaten by one hand. The Wakifundi, moreover, owing to their prolonged and stubborn resistance, were ordered to send some of their number, un the death of it Sultall of Vumba, to stand at the dours of the deceased's house. ${ }^{7}$

The majority of the conquered people, however, unwilling to accept peace on such degrading terms, left the towns of their birth and migrated elsewhere, some few to Jomvu, near Mombasa, whilst others went to Mtangata and Saadani and to other towns in what is now German East Africa. Those who remained had to comply with the terms of the peace, and these rules are observer by their descendants to the present day.

There are two large drums at Vanga which are believed to have been made at this time in commemoration of the victory over the eight towns. They are very massive and are grotesquely carved.

In 1630 A.J., about the time when Mwana Chambi Chandi Ivor sat on the throne of Vumba, the l'ortugueses at Mombasa were all massacred at the instigation of the Sultan of that town, named Yusuf (otherwise called Don Jeronymo Clingoulia), who, after being educated at Goa, had been converted to the Christian faith in 1627. Don Jeronymo seized the fort and suecessfully resisted

1 . Lute, 1. $2 \% 6$, note 12.

slinte, j. 279, note 4.

- Manjauli is now called Manzil. Iride p. 279, note 4 .

1 Mwiyuni is now called Alene. Vide p. 279, note 5.

"Mdragoni was built near the spot where the Government station Shimoni nuw stands, un tile wainland opposite Wasin town, and the ruins of a mosque are to be seen to the present day. The Wasegeju, who have a settlement hard by, have turned the site of the old town into a burial-ground.

${ }^{6}$ Kifundi is now called Shirazi, and is situated a short distance up the Vikuarani stream, a rivulet entering Funzi Bay. In point of size it must have rivalled Vumba Kuu itself, and the ruins of stone mosques, wells, holises, walls and graves are still to be seen in a state of good preservation. The war between the Wavumba, i.e., the people of Vumba, and the Wakifundi is sicid to have lasted seven yeals.

i linte, p. 280 , note 3 . 
an attack on the part of the Portuguese under the command of Don Francisco de Moura, who, with a large fleet, anchored off Mombasa on the 10th of January, 1632. Before commencing operations, the Portuguese General, we are informed in "Relaçấo da perda e restauraçấo de Mombaça do que lá aconteceo," wrote to the "King of Uumba, Mana Chamby Chande, a neighbour of Mombasa and a great eneny of the rebel," asking for aid. The help did not arrive, and Don Jeronymu, having captured two of the Portuguese vessels, dismantled the fort, burnt the city and escaped to Arabia. ${ }^{1}$

Mwana Chambi Chandi Ivor was the last of the Sultans to be buried at Vumba Kuu. An enormous gravestone was erected over the spot where lis remains were interred, and each succeeding holder of the office has been enthroned on this stone. Unfortunately, as has been already stated, this grave, together with other's, was pulled to pieces some three years ago, and the place is now only marked by a few small heaps of hewn blocks. ${ }^{2}$

On the cleath of Mwana Chambi Chandi Ivor, Mwenyi Kae bin Mwenyi Musa ba-Amiri was elected sultan. He chose for himself the nickname of Kitvu Kimoja, i.e., one head. It is uncertain what meaning this is supposed to convey, and the following explanations have been given me for the name:1. That the sultan intended listening to and deciding all disputes himself ; 2. That he was an only son; and 3. That he prophesied that he would be the last of the chieftains of Vumba, Kuu.

Shortly after his election, Mwana Chambi Chandi Kitwa Kimoja had the misfortune to lose one of his sons, a boy named Mwenyi Pembe bin sultan Mwenyi Kae. The child had gone to Wasin island with some fishermen and was playing on the beach when a Portuguese ship hove in sight. A boat was, sent on shore, and the boy fearlessly approached the white men. On the sailor's uffering to take him on board, he went with them and was never seen again.

During the reign of this chieftain the whole country was overrun by a tribe called the Wadoe, cannibals, who hailed from near Dar-es-Salaam, the capital of German East Africa. On one occasion, they went as far as Mombasa, killing everybody who crossed their path and carrying off the flocks and herds. Amongst others who suffered from the raid of these savages were the relations and descendants of the late Mwenyi Chandi bin Sheikh, the first Mwana Chambi Chandi of Vumba. On their way home, the Wadoe stopped at Vumba Kuu bul did no harm to the inhabitants and, having remained there a few days, they returned with their spoils to their own country.

A short while afterwards a report reached Mwana Chambi Chandi Kitwa

1 Bibliotheca Nacional de Lisboa. Codice Manuscripto, No. 7640. An anonynous and undated work written about the middle of the seventeenth century. For further particular's concerning Don Jeronymo, vicle Strandes, p. 209.

2 Inte, p. 279 , nute 8 .

- Kae is an abbreviation for Abubakari. This Sultan's real name was Mwenyi Abubakar.i bin Mwenyi Musa ba-Amiri. 
Kimoja that the relations and descendants of the late Mwenyi Chandi bin Shcikh, on hearing that the Wadoe had stopped at his town, had presumed that he and they were allies, and had decided to avenge themselves on the inhabitants of Vumba. Fearing an attack, the people left their homes and settled at Jimbo and at other fishing villages in the neighbourhood. Here they remained for some years, their houses, in the meantime, going to ruin.

Kitwa Kimoja died at Kigomeni and was buried at Bandani, a small wood near Vanga. With him died the last of the Mwana Chambi Chandi and the last of the chieftains of Vumba Kuu.

The next person selected to fill the honourable post of Sultan of Vumba was one Seyyid ${ }^{1}$ Abubakari bin Sheikh el-Masela-ba-Alaui, a Shereef, ${ }^{2}$ whose mother, Mwana Mkasi binti Mwenyi Musa ba-Amiri, was a sister of the late Mwana Chambi Chandi Kitwa Kimoja. ${ }^{3}$

Seyyid Abubakari chose for himself the nickname of Ruga, which, in the Kisegeju dialect, means the strength of a bull. He dropped the title of Mwana Chambi Chandi and assumed that of Diwan.

As the people of Vumba Kuu still feared an attack from Mombasa, many of them went, with Diwan Ruga at their head, to settle on Wasin island. Here they laid the foundations to a large city, which, a generation later, rivalled in extent and importance the former seat of the Sultans, Vumba Kuu.

The island of Wasin is some three miles in length, and, on the west side, about one mile in breadth. It is separated from the mainland by a channel which is three-quarters of a mile wide, and which forms one of the best harbours on the coast.

The origin of the word $W a \sin$ is lost in oblivion. The port way doubtless

1 All descendants of the prophet, unless promoted through some act of their own or of an uncestor to the rank of "Sheikh," are addressed by the title Seyyid (Lord) or Sherifu (Shereef). These titles appear, in some instances, to form a part of a Shereef's name.

2 Sultan Abubakari bin Sheikh's pedigree, as copied by his son, Omari, from a document brought from Mecca by one of his ancestors into Abubakari bin el-Fakihi Mwalimu Saleh's book, is as follows :- "Sultan Seyyid Abubakari, ibn Seyjid Sheikh, ibn Seyyid Abubakari, ibn Seyyid Omari, ibn Seyyid Abubakari Masela-el-ba-Alui (the first of this family to come to East Africa), ibn Seyyid Ahmed, ibn Seyyid Sheikh, ibn Seyyid Abubakari, ibn Seyyid Ali, ibn Seyyid Ahmed, ibn Seyyid Abdullah, ibn Seyyid Mohamed, ibn Seyyid Alui, ibn Seyyid Abdullah, ibn Sheikh Ali, ibn Sheikh Abdullah ba-Alui, ibn Sheikh Alui, ibn Seyyid FakihiMohamed, ibn Seyyid Ali-Mkadam-Turuba, ibn Sheikh Mohamed-Sahebu-Marabati, ibn Sheikh Ali-Khali-el-Kasim, ibn Seyyid Alui, ibn Seyyid Mohammed, ibn Seyyid Alui (fron whom the family received its surname), ibn Seyyid Abdullah, ibn Seyyid Ahmed, ibn Seyyid Isa, ibn Seyyid Mohamed, ibn Seyyid Ali el-Arthi, ibn Seyyid Jafer-Sadik, ibn Seyyid Mohamed el-Bakir, ibn Seyyid Zeina-el-Abidnia-Ali, ibn Seyyid Husein, ibn Ali (who married the Prophet's daughter Fatuma), ibn Abetwahib." The Prophet's pedigree is carried back some fifty other generations and eventually reaches Adam. As it is given at length in the Koran, it is unnecessary for me to record it here. The original pedigree which came from Arabia was burnt, I am informed, at Ormuz, in 1895.

3 Mwenyi Musa ba-Amiri had one other daughter, Mwandazi, who was married to Mwenji Hija bin Mwenyi Husein, a grandson of Mwenyi Chambi bin Sheikh, the first Mwana Chambi Chandi of Vumba. 
known to the first Asiatic mariners who navigated these waters, and, according to Drs. Tomaschek and Bitter, ${ }^{1}$ a Christian priest, a descendant of one of the Syrian missionaries who settled on Socotra Island shortly after the death of Our Lord, journeyed about the year 550 A.D. to Auxine (Wasin), from whence he travelled to Taprobane (Ceylon). The name Wasin also appears in several ancient maps, notably in one published in 1554 .

The Portuguese had no settlements there, but their ships occasionally paraded the coasts and sometimes called at the various towns. There are, at the present day, three towns on the island, Wasin proper, facing the mainland, Kunguni, a hamlet on the south side, built on the site of the fishing village of Mwana Chambi Chandi Kitwa Kimoja's time, and, on the eastern point, a settlement of Wokifundi.

The town of Wasin, although not so large as it was a century and a half ago, is still an important centre and has long been the chief market on the East Coast of Africa for boriti wood, obtained from the mangrove trees which abound in the neighbouring creeks. It contains several stone houses and three mosques; two of the latter were built some seventy years ago by Ahmed (nicknamed Mkulu) bin Mwenyi Mkuu el-Hasraji-el-ba-Urii, whilst the third was erected by Diwan Hasan (a son of Diwan Ruga), and was completer, as we are informed by an inscription carved by Sheikh bin Mwenyi Mui el-Hasraji-el-ba-Urii, on the birthday of Mwana Siti binti Diwan Hasan, the 23rd day of Auwal, 1162 A.H. (1749 A.D.). There are also the ruins of another mosque which was built by Kalaha, the agent at Wasin of Ahmed bin Mohamed, the Mazrui Governor of Mombasa from 1194 to 1229 A.H. (1780-1814 A.D.), ${ }^{2}$ and of several other stone houses. One of the latter, which was formerly the property of Sheikh bin Mwenyi Husein (nicknamed Akida) ba-Amiri, is believed to have treasure buried beneath its floors. ${ }^{3}$

Fresh water is unobtainable on the island itself, although two wells were sunk in the soft coral rock by Diwans Hasan and Sheikh. All water required for drinking purposes has, in consequence, to be procured from the mainland immediately opposite Wasin town. This is done by means of water-tight boats, the rowers sitting in the water which is afterwards to be consumed.

There are numerous gravestones on the island, but, as none are dated, they are of little importance. Many of the memorial inscriptions, however, which are of some interest, have been irretrievably damaged by the chisels of vandalic chinahunters from our ships of war. ${ }^{4}$

Diwan Ruga, having established himself at Wasin, proceeded to amass great wealth, chiefly through trading with the interior for ivory and slaves. He thus

1 Die topographischen Capitel des indischen Seespiegels Mohit, p. 29 (Vienna, 1897).

2 The Story of Mombasa.

- Burton in his Zanzibar, vol. ii, page 110, whilst describing a visit to this island, says : "By way of revenge, I dropped a hint about buried gold which has doubtless been the cause ot aching arms and hearts to the churls of Wasin." Is this the origin of the tradition ?

* Tt was formerly customary here, as elsewhere on the East Coast of Africa, to ornament the graves by fixing china dishes and plates into the stones. 
became one of the best known Sultans on the coast, and after Mombasa had been re-occupied by the Portuguese in 1728 A.D., Conde da Ericeira D. Luiz (afterwards the first Marquez de Louriçal), who was Viceroy of India from 1717 to 1720 , mentions in his Noticias de India desde o fim do Governo de Vice Rey Vaseo Frernandez Cesar athe o fim do anno de 1738 an que governa o Vice Rey Conde de Jandemil, ${ }^{1}$ that the King of Vumba submitted together with other princes to the Mombasa Government. He writes as follows :-

"Dentro de poucãs dias forão sogestar-se an Goveruo dã Mombaça, Moinha Macombe, Rei de Oacone, ${ }^{2}$ Mcameruruba, Rei de Mitangota, ${ }^{3}$ Mannchambe, Rei do $V u m b a$, Moinha Chambe, ${ }^{4}$ Rei de Tanga, Bensultan Manya, Rei da Ilha de Pomba, ${ }^{5}$ " por Anfalumen Assane," Rei de Zanzibar, foi dar obedencia em seu nome seu filho Muinha Mocu."

In another contemporary report the King of Vumba is called Mana Chame, and it is stated that he together with the other chieftains mentioned above went to Mombasa to pay homage to the Portuguese.

Diwan Ruga was thrice married and had issue by his wives fifteen children. He also had by concubines, twenty-five other children, twenty-three of whom are believed to have died in infancy or without issue. His first wife was his cousin, Mwana Musa binti Mwenyi Kae ba-Amiri (a daughter of Mwana Chambi Chandi Kitwa Kimoja). By her he had issue two sons, Seyyid Ibadi (nicknamed Miongo), the head of what was, at a later date, called "the Kigomeni family," and Sheikh, who, according to the inscription on his grave, was buried at Kigomeni in 1202 A.H. (1787 A.D.).

Diwan Ruga's second wife, who lived at Wasin, was Mwana Jumbe binti Mwenyi Umanzi bin Sheikh el-Hasraji-el-ba-Urii of Ozi. ${ }^{7}$ She bore him twelve children, of whom her eldest son, Omari, died without issue on the sixth day of the seventh month, 1148 A.I. (1735 A.n.). ${ }^{8} \quad$ The most important of her other sons were Hasan, afterwards Diwan, the head of what was called, at a later date, "the Wasin family"; Mwenyi Sagafu, who was buried at Kigomeni in 1201 A.H. (1786 A.D. $)^{9}$; Idarus, who was considered a wizard, and at whose grave at Wasin, the Wadigo, in dry seasons, offer up prayers for rain; Alaui, the ancestor of the third and fourth Diwans of Wasin; and Kasim, who was the first person to settle on the plot of ground now called Vanga. The latter was greatly liked by the Mazaran, whom he accompanied when the governor of Mombasa, Ali bin Athman el-Mazrui, attacked the native chieftain of Zanzibar. During this expedition

1 Bibliotheca Nacional de Lisboa. Codice Manuscripto, No. 465.

2 Is this Mdragoni? (Ante, p. 282, note 5.) According to tradition, all the inhabitants after the fall of this town in Mwana Chambi Chandi Ivor's reign went elsewhere, and it was allowed to fall into ruins.

3 Mtangata, a town some twenty miles south of Tanga, German East Africa.

${ }^{4}$ Mwenyi Chambi. Ante, p. 277, note $4 . \quad{ }^{2}$ Pemba.

- Mfalme Hasan. Ante, p. 277, note 4.

7 Ozi is a town not far from Lamu.

${ }^{8}$ Abubakari bin el-Fakihi Mwalimụ Saleh's book.

9 Memorial inscription. 
Ali bin Athman himself was killed by his nephew Khalaf bin Khatibu bin Athman in 1.167 A.r. (1754 A.D.) and was buried at Zanzibar. ${ }^{1}$

Diwan Ruga's most renowned daughter was Mwana Siti (nicknamed Wa Mwana Chambi). She was married to Abubakari (nicknamed Bajios) bin Twahiri el--Jadid and thus became the ancestress of the Diwans of Vanga. This Mwana Siti binti Diwan Ruga was appointed, accoraing to an old Vumba custom, judge in all matters in which the fair sex was concerner. These lady judges have been regularly elected ever since, and, on the death of onc, another is chosen.

Diwan Ruga married thirclly a lady of Pemba, by whom he had issue one son, Sherifu Ibadi (nicknamed Mwenyi Pati).

Diwan Ruga died on the fourth day of the first month, 11 5̃ A.H. (1742 A.D.), ${ }^{2}$ and was buried at Wasin.

His second and eldest surviving son by Mwana Jumbe binti Mwenyi Umanzi el-ba-Urii, named Hasan, was aged about forty when Diwan Ruga died. The people of Wasin unanimously elected Shereef Hasan to fill the vacancy causer by his father's death, and he was enthroned at Vumba Kuu in 1157 A.H. (1744 A.D.). ${ }^{3}$ Owing to his name meaning blessed, he did not change it: he is thus known as Diwan Hasan.

The inhabitants of Kigomeni, at the instigation of the head of the Ba-Amiri, Mwenyi Mkuu bin Sultan Mwenyi Kae (the eldest son of Mwana Chamli Chandi Kitwa Kimoja) refused to acknowledge Diwan Hasan and wished to appoint, in his stead, his half-brother Seyyid Ibadi (nicknamed Miongo) bin Diwan Ruga. The latter certainly had a better clain, if it was a question of hereditary rights, owing to his mother being a daughter of Mwana Chambi Chandi Kitwa Kimajo, but he declined becoming Hasan's rival. Mwenyi Mkuu and his followers at Kigomeni, however, still rejected the choice of the people of Wasin, and now selected a member of another branch of the Ba-Alaui family, Sherifu Ali bin Abubakari, as their representative. The table ${ }^{4}$ on p. 288 will show his relationship to Diwan Hasan.

Sherifu Ali bin Abubakari el-ba Alaui was duly enthroned at Vumba Kuu and took the name of Maere, which means clear weather after the storm. Thus, there was one Diwan at Wasin and another at Kigomeni.

The latter, after holding office for ten years, died on the 24th day of Rajiabo, 1168 A.H. (1755 A.D.). ${ }^{5}$ Both he and his patron, Mwenyi Mkuu bin Sultan Mwenyi Kae were very poor, and no money was forthcoming to pay for the ordinary funeral feast. Mwenyi Mkuu at last decided to compromise with Diwan Hasan and promised, if the latter would pay for the feast to be held in honour of

1 The Story of Mombasa.

a Abubakari bin el-Fakihi Mwalimu Saleh's book.

a Jloid.

4 This pedigree and the dates are taken from Abubakari bin cl-Takih Mwalimu Saleh's hook.

s Abubakari bin el-Fakihi Mwalimu Saleh's book; 


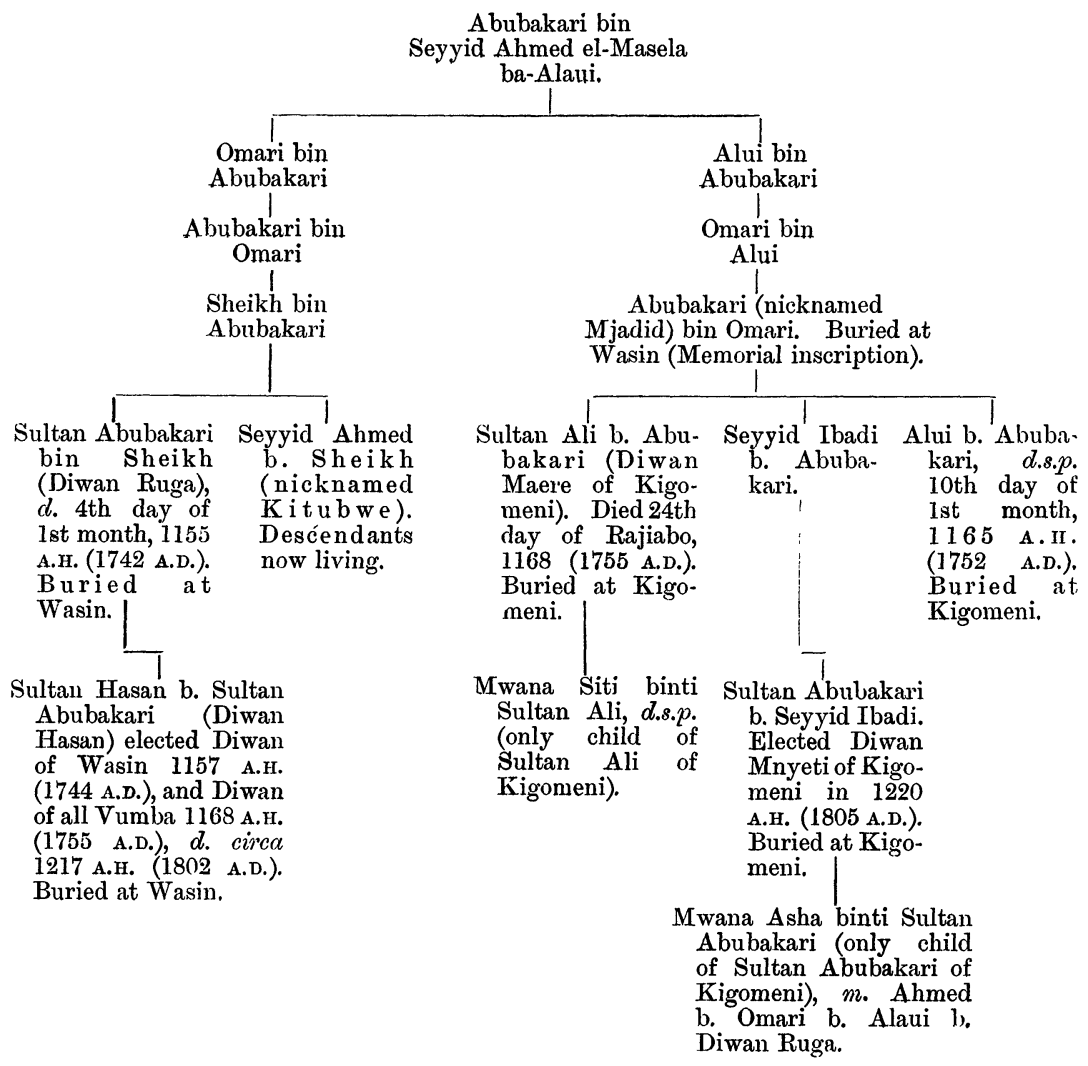

TABLE SHOWING THE RELATIONSHIP BETWEEN DIWAN HASAN AND SHERIFU BIN ABUBAKARI EL-BA-ALAUI.

the death of his late rival, that he (Diwan Hasan) would alone be acknowledged as Sultan from Kwale to Likoni. Diwan Hasan accepted the offer and paid for and was present at Diwan Maere's funeral feast, after which he returned to Wasin and reigned as Sultan of Vumba until his death in circa 1217 A.H. (1802 A.D.).

Diwan Hasan paid several visits to his mother's relatives at $\mathrm{Ozi}$, and on one occasion was presented with an ivory horn (siwa). This horn, which weighs ahout sixty pounds, is still in the possession of the people of Vanga.

During the latter years of his life, Diwan Hasan was, owing to his great age, (quite incapable of performing any of the duties of his office, and his eldest and only surviving son, Abubakari bin Sultan Hasan, who was born on the twelfth clay of the third month, 1148 A.H. (1735 A.D.), ${ }^{1}$ acted in his stead.

\footnotetext{
1 Abubakari bin el-Fakihi Mwalimu Saleh's book.
} 
Diwan Hasan married four times. His best known sons are Seyyid Ahmed, who was born on the 27 th day of the 6th month, 1149 A.H. (1736 A.D.), ${ }^{1}$ and Sherifu Ali, who was buried at Kigomeni in 1200 A.H. (1785 A.D.). ${ }^{2}$

On the death of I)iwan Hasan, his son Abubakari was unanimously chosen as his successor and was duly invested with the vunda. ${ }^{3}$ Before he could be enthroned at Vumba Kuu, however, Sherifu Abubakari was taken suddenly ill and died.

A Shereef, named Sheikh Hasan bin Salim min'-Ali-Sheikh-Abubakari-bin Salim-el-Mansabi, ${ }^{5}$ who, by his mother, a daughter of Diwan Hasan, was a greatgrandson of Diwan Ruga, and who had married a daughter of the late Seyyid Abubakari bin Diwan Hasan, was accused by his enemies of having killed his father-in-law by witchcraft in order to be chosen Diwan himself. Be that as it may, Sheikh Hasan bin Salim obtained a portion of the wealth left by Diwan Ruga, to the exclusion of the lawful heirs, was elected Diwan and was eventually enthroned at Vumba Kuu. He chose for himself the name of Sheikh (pronounced Shehe) in memory of his ancestor Sheikh Abubakari bin Salim el-Mansabi, who, in his time, was a great and learned man.

Some of the people of Kigomeni again opposed the choice of their relations of Wasin, and the more wealthy of them collected a sum of money and appointed the nephew of the late Diwan Maere, by name Abubakari bin Seyyid Ibadi el-baAlaui, who had been earning a precarious livelihood in Zanzibar, as their Sultan. Great friction was thus once more caused between the inhabitants of these two towns, and all the supporters of Diwan Sheikh living at Kigomeni were obliged to quit their homes and settle on the island of Wasin.

This, too, formed a fresh pretext for the Wadigo to enter on a civil war-a no very uncommon matter with that tribe-and their chief, named Kubo Mwakikonga of the Mohindzano or Kinangala clan, enraged at the people of Kigomeni asking his underling, Mwana Moki Mwabubu of Kilulu ${ }^{6}$ for an escort to take them to Vumba

1 Abubakari bin el-Fakihi Mwalimu Saleh's book.

2 Memorial inscription.

4 Min is equivalent to "of the family of."

3 Ante, p. 279, note 2.

5 Sheikh Hasan's pedigree, according to Abubakari bin el-Fakihi Mwalimu Saleh's book is as follows:- "Sultan Hasan, ibn Sheikh Salim, ibn Sheikh Ahmed, ibn Sheikh Nasir, ibn Sheikh Ahmed, ibn Sheikh Salim, ibn Sheikh Ahmed, ibn Sheikh Abubakari, ibn Sheikh Salim, ibn Sheikh Abubakari, ibn Sheikh Ahmed, ibn Ali, ibn Sheikh Abubakari, ibn Salim." Sheikh Abubakari ibn Salim's pedigree, I am informed by the Sheikh-ul-Islam, or chief Cadi for the East Africa Protectorate, is as follows :- "Sheikh Abubakari ibn Salim, ibn Abdurahman (Segafu), ibn Mahomed (Maul-Abuliwa), ibn Ali, ibn Alui, ibn Mahomed, ibn el-Fakihi Makadam, ibn Ali, ibn Mahomed Sahebu-Marabati, ibn Ali, ibn Alui, ibn Mahomed, ibn Alui, ibn Abdullah, ibn Ahmed, ibn Isa, ibn Mahomed, ibn Ali, ibn Jafer, ibn Mahomed, ibn Husein, ibn Ali (who married the Prophet's daughter Fatuma)." It will be noticed that, with the exception of Zeina-el-Abidnia-Ali, this pedigree coincides for some generations with that of the Ba-Alaui family.

- Kilulu is a hill, 900 feet high, on the sea coast, ten miles south of Jasin. Mwana Moki had stones carried to the top of this hill and there built himself a house. After his death he

Vol. XXX (N.S. III). 
Kuu, attacked the new Diwan's party while on its way to the enthronement, killing several of its members and forcing the Diwan himself to fly for his life.

Some days later, however, chiefly through the intercession of his rival, Iiwan Sheikh, Seyyid Abubakari bin Seyyid Ibadi el-ba-Alaui was enthronerl at Vumba Kun and chose for himself the name of Mnyeti, meaning Patience.

On the $23 \mathrm{rd}$ of the seventh month, 1236 A.H. (1821 A.D.), ${ }^{1}$ war was declared between Seyyid Said bin Sultan, the fourth Albusairli Imam of Muscat, and the Mazrui governor of Momhasa, Ahdullah bin Ahmed, who, on his accession in 1229 A.r. (1814 A.D.), ${ }^{2}$ had (lespatched to his lord, instead of the customary presents, a mail shirt, a flask of powder and a wooden spoon. After Pate had fallen before the Arab invaders, the island of Pemba was threatenel. On hearing of this, Diwan Sheikh thought it would be wiser to leave Wasin until hostilities should be at an end, so he went with all his adherents to the mainland. Some of the people, including the Diwan himself, settled at Vanga-then only a sinall fishing village - whilst others went to live at the various towns along the coast.

Shortly after the evacuation of Wasin, one of Seyyid Said bin. Sultan's generals, Amiri Ahmed bin Mahomed, called at the island on his way to Pemba, and, presuming that the deserted town which he found there belonged to the enemy, he destroyed all the houses and other buildings, leaving untoucherl only the mosque built by Diwan Hasan.

Diwan Sheikh did not long survive his change of residence. He died in the first year after Suliman bin Ali harl been chosen Governor of Mombasa ${ }^{3}$ (1239 A.Ir. or 1824 A.D.), and was buried at Bandani, near the grave of Mwana Chamli Chandi Kitwa Kimoja.

Diwan Mnyeti had predeceaserl Diwan Sheikh and had heen buried with his uncle, the late Diwan Maere at Kigomeni.

Owing to the Fnglish having placed Mombasa under their protection, ${ }^{4}$ there was now no longer any fear of Seyyid Said attacking Wasin, and the people, with the exception of those who harl gone to Tanga, returnerl to their homes and rebuilt their houses. Those who had followed the late Jiwan to Vanga remaincl at that town.

Some dispute arose hetween the latter and the people of Wasin as to where the feast to be given in homour of Diwan Shejkh's death should he held, each party advocating its own town. The former had the better of the argument, and the feast was consequently prepared at Vanga.

was buried with five of his brothers on the summit, and his grave can be seen to the present day. Mwani Moki belonged to the Kombo family of the Driribe clan.

1 The Story of Mombasa.

2 Ibid.

3 Abubakari bin el-Fakihi Mwalimu Saleh's book. According to The Story of Mombasa, Suliman bin Ali el-Mazrui was chosen governor of that town in 1238 A.H. (1823 A.D.).

+ Sir Arthur Hardinge in his Report on the condition and progress of the East Africa Protectorate from its commencement to the $20 t h J u l y, 1897$, writes, "Suliman bin Ali placed himself under the protection of Captain Owen of H.M.S. 'Barracouta,' in 1823. The British Govern. ment, however, repudiated the Protectorate, which was withdrawn two years later." 
$\Lambda$ ccording to an old custom, it is necessary for all the relations of a deceaserl Sultan of Vumba who intend taking part in the funeral feast given in his honour to he present when a certain ox is slaughtered, and if the ox is slanghtered whilst any one is absent, it is considered as an insult to the absentee. The ox, which is always the largest that can be procurerl, is first of all given a name. On the present occasion it was callerl "Mjaka wa Chandi."

On the day appointed, one Seyyid Ahmed bin Alaui bin Sultan Abubakari (a grandson of Diwan Puga) purposely ahsented himself from the revels, and the ox was slaughtered before he arriverl. When he appeared upon the scene, he called upon all present to witness the insult which had been offered him and returnerl to Wasin without taking part in the feast. He was followed by most of the Ba-Alaui and Ba-Amiri and was shortly afterwards proclaimed Diwan. The Vanga people, however, refused to acknowledge him and wished to appoint Sheikh Nasir bin Sultan Hasan (a son of the late Diwan Sheikh) as his father's successor, but the latter, now an elderly man, ${ }^{1}$ did not desire the honour and proposed a Shereef, named Seyyid Ahmed bin Abubakari (Dani) bin Abubakakari (Bajios) bin Twahiri bin Ahmed bin Husein el-Jadid, the son of his father's half-sister, Mwana Alaui binti Mfalme Bakiri of Zanzibar, and the great-grandson as well as the great-great-grandlson of Diwan Ruga. ${ }^{2}$

As there was now an open breach between the inhabitants of Wasin and Vanga, and matters began to look serious, it was decided that the whole case should be referred to the Mazrui Governor of Mombasa, Suliman bin Ali.

At first, the judge favoured the suit of Seyyid Ahmed bin Alani, but seeing that the Vanga people absolutely refused to acknowledge him and that Sheikh Nasir bin Diwan Sheikh had inherited some of Diwan Ruga's great wealth together with the articles appertaining to the Diwan's office, he decided that both Seyyid Ahmed bin Alaui and Seyyid Ahmed bin Abubakari should be electerl Diwan. Thus, the houses el-ba-Alaui and el-Jadid were represented respectively at Wasin and Vanga.

The former Diwan named himself Kikcmbala and the latter Pinda. The meaning of Kikambala in the Kidigo dialect is tether. Seyyid Ahmed bin Alaui called himself thus in order to show that, as an ox could be fastened by a piece of cord, so would he be tied to his post by duty. The meaning of Pinda is to bend a bow preparatory to shooting an arrow. Seyyid Ahmed bin Abubakari's idea in giving himself this name was to make the people think that he was always ready to receive an enemy.

Both men were much respected, but, of the two, the Wasin Diwan had the greater influence over the Wasegeju and Wadigo, which latter tribe, under the warlike chief Kubo Mwakikonga, was now in the zenith of its power. Diwan

1 According to Abubakari bin el-Fakihi Mwalimu Saleh's book, Sheikh Nasir was born on the 19th day of the 5th month, 1189 A.H. (1775 A.D.). He was therefore fifty years of age when the above recorded event happened.

2 Ibid. 
Pinda was considered a great wizard and medicine-man and was much favoured by the Mazaran, with whom he spent the half of each year.

As the Vanga Diwan had inherited the drums of Mwana Chambi Chandi Ivor (vide p. 282) and the ivory horn of Diwan Hasan (vide p. 288), the people of Wasin had three large drums and a long wooden horn made.

In 1241 A.H. (1826 A.D.) Salin bin Ahmed el-Mazrui deposed his cousin Suliman bin Ali, ${ }^{1}$ and on the 23 rd day of the 5th month, 1243 A.H. (1828 A.D.), ${ }^{2}$ he was obliged to surrender the fort at Mombasa to the Muscat Prince, Seyyid Sairl bin Sultan. He was, however, permitted to remain as hereditary governor of the town and to retain one half of the revenues. When Seyyid Said had once obtained possession of the fort, which he placed under the charge of a Jemidar," named Shoho, he broke his pledge to the Mazaran and appointed Nasir bin Seliman bin Kasim Ismaili Governor of Monbasa. Incensed by this breach of faith, Salim bin Ahmed attempted unsuccessfully to poison his enemy's representative, who thereupon retired to the fort.

One of the Imam's generals, Alimas hadim ${ }^{4}$ Seyyid Said, was sent from Zanzibar to recover the town of Mombasa, which had been seized by the Mazaran, and to succour the inmates of the fort, who were in such straits for want of food that they were reduced to eating rats. $^{5}$ On his way thither, Alimas stopped at Wasin and signed a treaty of peace with Diwan Kikambala. Noticing some cowry shells on the sea-shore which belonged to his enemy, Salim bin Ahmed, Alimas begged the Diwan to allow him to take them away with him to use against their owner instead of shot. Diwan Kikambala, possibly glad of an opportunity to avenge himself on the patrons of his rival, readily agreed, and three gizlahs (1080 lbs.) of the shells were put on board the Zanzibar boats before Alimas set sail for Mombasa.

On the conclusion of peace between the Mazaran and the Muscat Arabs in 1249 A.H. (1833 A.D.), ${ }^{6}$ the Diwan of Wasin was told that Salim bin Ahmed was angry with him for the part he had played in handing over the cowry shells to Alimas, and he was advised to go to Mombasa and wait on the Governor. $\mathrm{He}$ therefore went, accompanied by a large following of Arabs and, as a hint, attended by a small body-guard of Wadigo and Wasegeju.

Salim bin Ahmed, fearing to do anything to him openly, on account of his influence over the natives, received him well, and great festivities were given in his honour.

On the day before Diwan Kikambala intended returning to Wasin he was taken slightly ill, and Mahomed bin Ahmed, Salim's brother, gave him some medicine. Shortly after he had drunk the concoction, he became much worse and expired in a few hours. He was buried in the grave-yard, called "Kwa Masheikh," in the "Mji wa kale" portion of Mombasa.

\footnotetext{
1 The Story of Mombasa.

3 A jemidar is a native subaltern officer.

5 The Story of Mombasa.
}

2 Ibid.

"The meaning of hadim is "the slave of."

- Ibid. 
Having ridded himself thus successfully of his enemy, Salim bin Ahmer thonght it alvisable to disperse the relations of the deceased. In consequence, he ordered them to return to their homes, to break down their houses and to go and live on the mainland. This they did, remaining at Vanga and at other cuast towns till the final capture of Monibasa by Said lin Sultan, who treacherously seized Rashid bin Salim, a son and successor of Salim bin Ahmed, and sent him with twenty-four of his relations to starve in the dungeons of Bunder-Abbas, ${ }^{1}$ when the Wasin people again took up their abode on the island.

In the meantime, Diwan Pinda had quarrelled with the Mazaran, owing to their brutal treatment of one of the Mwenyi Chambi of Tanga, ${ }^{2}$ and had joined their enemy, Seyyid Sail bin Sultan, at whose court he now spent the greater part of his time. He twice acconmpanied the Sultans of Zanzibar to Siu, ${ }^{3}$ being present at the defeat of Seyyid Said's forces by the chieftain Mataka, and later, at the bombardment and laking of that town by Seyyid Majid bin Said. Diwan Pinda also twice visited the chieftain of Usambara, ${ }^{4}$ by name Kinweri, at the latter's cupital, Vuga. Although he rarely stopped at Vanga, the Diwan put that town in a state of defence by encircling it with a stone wall. ${ }^{.}$

In $127 \tilde{0}$ A.H. (1858 A.D.) the country was visited by cholera. According to the diary of one Abubakari bin Kasim bin Mwalimu Twahiri el-Jadid, no fewer than two hunclred and sixty-two persons died of this disease at Wasin in thirtyseven days.

Vanga was attacked in 1276 A.H. (1859 A.D.) by a horde of Masai, a wallike und nomad tribe inhabiting the plains between Kilima Njaro and Victoria Nyanza. Although at first repelled, they returned in greater numbers than before and finally forced the inhabitants to take shelter at Kigomeni. The invaders did but little damage to the lown and contented themselves with driving off the cuttle.

Sultan Ahmed bin Abubakari el-Jadid, otherwise called Diwan Pinda, died at

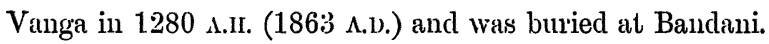

Un the return of the Wasin people to the island home of their ancestors in

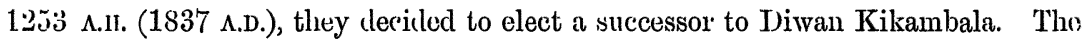
choice fell un seyyid Almed bin Nasir bin Alaui bin Diwan Ruga, who, however', died before he could be enthroned. His brother, Seyyid Alaui bin Nasir lin Alaui

1 This event took place, according to an inscription in the Friday Musque of Hamls Mlohamed Ali Rokhesh in Mombusa, on the 20th day of the 3id mouth, 1253 A.II. (1837 A.Dı).

2. Linte, p. 277, note 4 .

inte, 1. 277, note 2 .

' Usambara is the name given to the highlands at the back of 'Tinga, German East $\Delta$ fricit. On the slopes there are now numerous cuffee plentations. As a safeguard against attack, the natives build their villages in the middle of its densest woods, or on the summits of its highest hills.

s 'This seems to be the unanimous statement of the inhabitants of Vanga, but Sir Arthur' Hardinge in his Report on the condition and progress of the East Africu Protectorate from its commencement to the $20 t h \mathrm{Jul} y, 1897$, wriles, "Vanga (in 189.1) was surrounded by a stone wall said to date from the Portuguese times, portions of which arc still in existence." 
bin Diwan Iiuga, was then chusen in his steal. 'The latter, I an told, was a fine, handsome man with a long flowing beard; but, shortly after his election, he had the misfortume to become totally blind. The superstitious natives attributed both the death of Seyyid Ahmed bin Nasir and the blinding of his brother to the sorcery of Diwan Pinda; and this idea took such a firm hold on the minds of the people that it was decided to await the Vanga chieftain's death before Seyyid Alaut bin Nasir should be enthroned. In the first month of 1281 A.H. (1864 A.D.) Seyyid Twahiri bin Abubakari (I)ani) el-Jadid, who had been chosen by the people of Vanga to succeed his brother, the late IDiwan Pinda, was enthroned together with Seyyid Alaui bin Nasir el-ba-Alaui at Vumba Kuu. The Diwan of Wasin chose the name of Clinngu, meaning dawn, and the Diwan of Vanga that of Kilimia, ${ }^{1}$ meming the Pleiads. The former thus likened the long interregum which had followed Jiwan Kikambala's death to a tropical night, whilst the latter wished to show that, as the Pleiads are invisible for a short period during the year, so the people of Vanga had not been long without their chief.

The only work of note performerl by Diwan Kilimia was to improve the wall built by his brother round the town of Vanga.

During the month of liamathan, 1286 A.H. (December, 1869), a terrible war e of eholera again passed over the land. Four hundred and thirty persons died in fourteen clayss at Vanga and Wasin, amongst them the Diwan of Vanga himsclit, Sheikh Kasim bin Abdullah el-Menthiri (Diwan Kikambala's ('adi) and ejghty-l wo Arabs, of whom ten were virgins.' The Diwan, who died on the tenth of the month, was buried at Bandani.

In 1288 A.II. (1871 4.D.) Seyyid Almed bin Sultan Twahiri el-Jadid, a son bf Jiwan Kilimia, was selected by the people of Vanga to succeed his father. He chose for himself the name of Marithice (a corruption of Maritheces, which merans plenty), as a prediction that, so long as he lived, there would be no limine in the land. $\mathrm{He}$ is, however, better known by his former nickname s'culiu', which is a corruption of Cluuliuce, and means take.

Diwan Uliungu of Wasin clied in 1295 A.11. (1878 A.D.) and was buried with great pomp in the grave of his ancestor Diwan liuga. In 1800 A.11. (1883 4.11.) a suceessor was chesen in the person of Seyyid Nasir bin Alaui bin Diwan Kikambala, who, howerer, died on the 22nd of the the month, 130.2 A.Ir. (February, 1885 A.b.)," before he hatd been enthroned at Vumba Kuu. No other successor to Diwan Uliungu has since been chosen, and the drums, silver chain, wooden horn and

1 Kilimic means literally " that by which to cultivate." The Pleiads are not seen for two or three weeks in May or June, and their reappearance marks the commencement of the Indian corn and millet harvests. The following is a common native proverb :-“ Kilimia kikizama kwa jua huzuka kwa mvua, kikizama kwa mvua huzuka kwa jua," or " When the Pleiads set in sun, i.e., in sunny weather, they rise in rain; when they set in rain, they rise in sun." (Taylor : Ifrican Aphorisms.)

" Numbers, date and particulars taken from the diury of Abubakari bin Kasim bin Mwalimu 'Twalıiri el-Jadid.

3 Entry in Nasir bin Alatui's Kín'an manle by his son Mlaui bin Nasir. 
umbrella, etc., pertaining to the office of Diwan of Wasin are now in the possesssion of Seyyid Alaui bin Nasir bin Alaui bin Diwan Kikambala bin Alaui bin Diwan liuga, the Government Arabic clerk at Shimoni.

After the death of Seyyid Nasir bin Alaui bin Diwan Kikambala, the members of the Ba-Alaui family at Wasin were continually quarrelling as to who had the best right to be elected Diwan, and, in the years 1310 and 1311 A.H. (1892 and 1893 A.D.), assaults and disturbances of all kinds were of frequent occurrence. The I.B.E.A. Company's District Superintendent at Shimoni, tired at length of warning, ordered on one occasion, seven Shereefs to receive twenty-five lashes each. This sentence had the desired effect so far as the Company's officials were concerned, but it is probable that no Diwan of Wasin will ever again be chosen, so heartily do the rivals now hate one another.

Troublous times followed the election of Diwan Mirithia. Shortly after his succession, Sheikh Mbaruk bin Rashid el-Khelani-el Mazrui of Gasi sent him a haughty message demanding a free woman of Vanga as wife. The people refused and asked for and obtained aid from Sultan Barghash bin Said of Zanzibar. Sheikh Mbar'uk attacked Vanga but was repelled with loss.

In 1302 and 1303 A.H. (1884 and 1885 A.D.) the country was stricken hy famine, contrary to the Diwan's prediction, and thousands of the natives diod.

In 1304 A.H. (1886 A.D.) Sheikh Mbaruk bin liashid rebelled for a second lime against the authority of the Sultan of Zanzibar, and remembering his defeat some years before at the bands of the people of Vanga, he surprised that town and burnt and sacked it. The Diwan and most of the inhabitants lled to Manzi, in German East Africa, where they remained until Sheikh Mbaruk was eventually compelled by General Mathews to make his submission at Zanzibar to Seyyid Birrghash.

On July 24th, 1895, Sheikh Mbaruk again attacked and burnt Vingra. ${ }^{1}$ One of his generals, Ali bin Abdullah el-Mazrui, at the same time seized as hustages the persons of the Diwan and his Cadi (the present Liwali of Vanga) and sent thein, under a small escurt, to the Mizrui fortress at Mwele." On the road they stopled for the night at Miongoni, on the Umba niver. The Mdigo eldor of this village, one Mvuno of the Mwiyombo clam, remained true to the oath lakem by his chicf at the Diwan's enthronement. He beat his war-clrums, collected a large number of his tribesmen and resened the prisoner's, who escaped to Kwale in German territory, where they remained till hostilitics were at an end.

Diwan Marithia, who during the last few years of his life was recognised as Diwan of all Vumba, died childless on the bth day of the Gth month, 1315 A.It.

1 Vide Blue Book, Africu, No. 6 (1896), p. 12.

2 Mwele is a hill, lying at the southern end of the Shimba group, twenty niles to the west of Ciasi. From its summit a wonderful view can be obtained, the snow-covered heights of Kilima Njaro, summounting a long expanke of plain studded with isolated peaks, being visible on the one side, whilst, from ihe opposite slope, cinn be seen the whole coinst line, the Indian Oeean, and in the distance the Island of Pembit. 
(August 8th, 1897), and was buried at Bandani. In accordance with a proclamation issued by the Sultan of Zanzibar, Seyyid Ali bin Said, on the 1st of August, 1890, the late Diwan's slaves-ninety-six in number-were all set at liberty.

Since Diwan Marithia's decease no one has, as yet, been chosen to succeed him. There are, however, two claimants, viz.:-his brother, Sherifu Abubakari bin Diwan Kilimia el-Jadid and Sherifu Nasir bin Hasan bin Hasan bin Abubakari bin Seyyid Ahmed bin Diwan Ruga el-ba-Alaui, whose mother was Fatuma binti Diwan Kilimia, but neither of these persons have sufficient means wherewith to pay for the various feasts necessary before the election can take place. A rumour is being circulated that a woman, Mwana Shasha binti Diwan Kilimia, a wife of the Cadi of Wasin, Sheikh Rashid bin Kasim el-Menthiri, is also anxious to become Diwan; notwithstanding this lady's high position and great wealth, however, she has received but feeble support from the electors. Nevertheless, it is to be hoped that the ancient title will not be allowed to fall into complete abeyance, but that some duly qualified candidate may yet be chosen to make once more the time-honoured journey to the ruined city in the wood and thence return a crowned Diwan of Vumba.

\section{NOTES ON THE PEDIGREE OF THE DIWANS OF VUMBA.}

\section{Plate $X X I X$.}

1. Author of book in which the records of Vumba Ndogo were kept. This book was finished on the 7th of the 3rd month 1133 A.H. (1721 A.D.) after mid-day prayer.

2. Elected 1st Diwan of Vumba circa 1124 A.H. (1712 A.D.). Nicknamed Ruga. Died 4th of 1st month 1155 A.H. (1742 A.D،). Buried at Wasin.

3. Elected 1st Diwan of Kigomeni, 1158 A.H. (1745 A.D.). Nicknamed Maere. Died 24th of Rajiabo 1168 A.H. (1755 A.D.) buried at Kigomeni.

4. Father of Abubakari bin Ibadi, who was elected 2nd and last Diwan of Kigomeni in 1220 A.H. (1805 A.D.). Nicknamed Mnyeti. Died before 1239 A.H. $(1824$ A.D.) and buried at Kigomeni.

5. Died 10th of 1st month 1165 A.H. (1752 A.D.). Buried at Kigomeni.

6. Born circa 1117 A.H. (1705 A.D.). Elected 1st Diwan of Wasin in 1157 A.в. (174t A.D.), and 2nd Diwan of Vumba in 1168 A.H. (1755 A.D.). Nicknamed Hasan. Died circa 1217 A.н. (1802 A.D.). Buried at Wasin.

7. Born the year Hasan bin Diwan Ruga chosen Diwan of Wasin (1157 A.H. or 1744 A.D.).

8. Elected 3rd Diwan of Wasin in 1239 A.H. (1824 A.D.). Nicknamed Kikambala. Poisoned at Mombasa in 1249 A.H. (1833 A.D.). Buried in Mombasa.

9. Born 12th day of the 3rd month 1148 A.H. (1735 A.D.). Elected Diwan but died circa 1217 A.H. (1802 A.D.) before he was enthroned. Buried at Wasin. Issue several children.

10. Elected Diwan of Wasin but died, before he was enthroned, in 1253 A.H. (1837 A.D.). Buried at Wasin.

11. Elected 4th and last Diwan of Wasin in 1253 A.H. (1837 A.D.) Enthroned 1st month 1281 A.H. (1864 A.D.). Nicknamed Ukungu. Died 1295 A.H. (1878 A.D.). Buried at Wasin.

12. Issue several children. Buried at Wasin. One of his sons, Nasir bin Alaui, was elected Diwan of Wasin in 1300 A.H. but died, before he was enthroned, in 1302 s.l1. (1885 A.D.). 
13. Issue several children. Buried at Wasin.

14. Elected 2nd Diwan of Wasin, circa 1218 A.H. (1802 A.D.). Died in 1239 A.H. (1824 A.D.). Buried at Bandani near Vanga. Nicknamed Sheikh. No descendants living.

15. Elected 2nd Diwan of Vanga in 1280 A.H. and enthroned 1st month of 1281 A.H. (1864 A.D.). Died 10th day Ramathan 1286 A.H. (1869 A.D.). Nicknamed Kilimia. Buried at Bandani near Vanga.

16. Elected 1st Diwan of Vanga 1239 A.H. (1824 A.D.). Nicknamed Pinda. Died 1280 A.H. (1863 A.D.). Buried at Bandani near Vanga. Descendants living.

17. Living at Tanga, German East Africa. Candidate for the office of Diwan of Vumba.

18. Elected 3rd Diwan of Vanga in 1288 A.H. (1871 A.D.). Nicknamed Marithia. Acknowledged as 3rd Diwan of Vumba after 1311 А.н. (1893 A.D.). D.s.p. 6th of 6th month 1315 (August 8th, 1897). Buried at Bandani, near Vanga.

19. Said to be candidate for the office of Diwan of Vumba.

20. Her son, Nasir, is a candidate for the office of Diwan of Vumba.

[Editorial Note.-We are indebted for the MS. of this valuable paper to the kindness of the Foreign Office; in tendering our thanks we should like to point out lhow nuch Government servants, both in the colonies and in foreign countries, could do for Anthropology if their attention is once directed to the scientific and political importance of close observation of the races with whom they are brought in contact.

It has not been found possible to publish all the genealogical material ; the unpublished MSS. are accessible to students, and can be examined in the Library of the Institute.] 


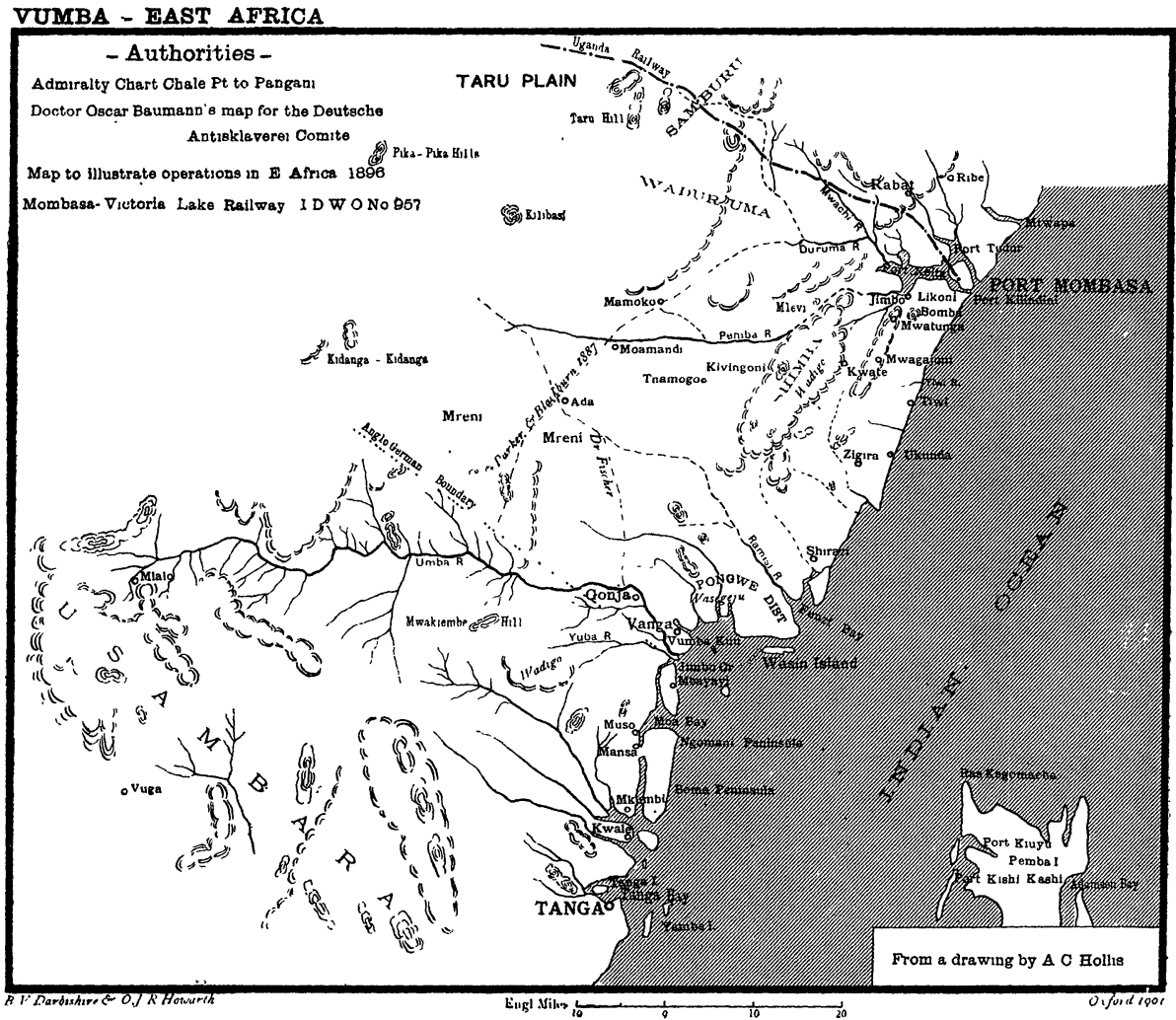

\section{VUMBA KUU - BAST AFRICA}

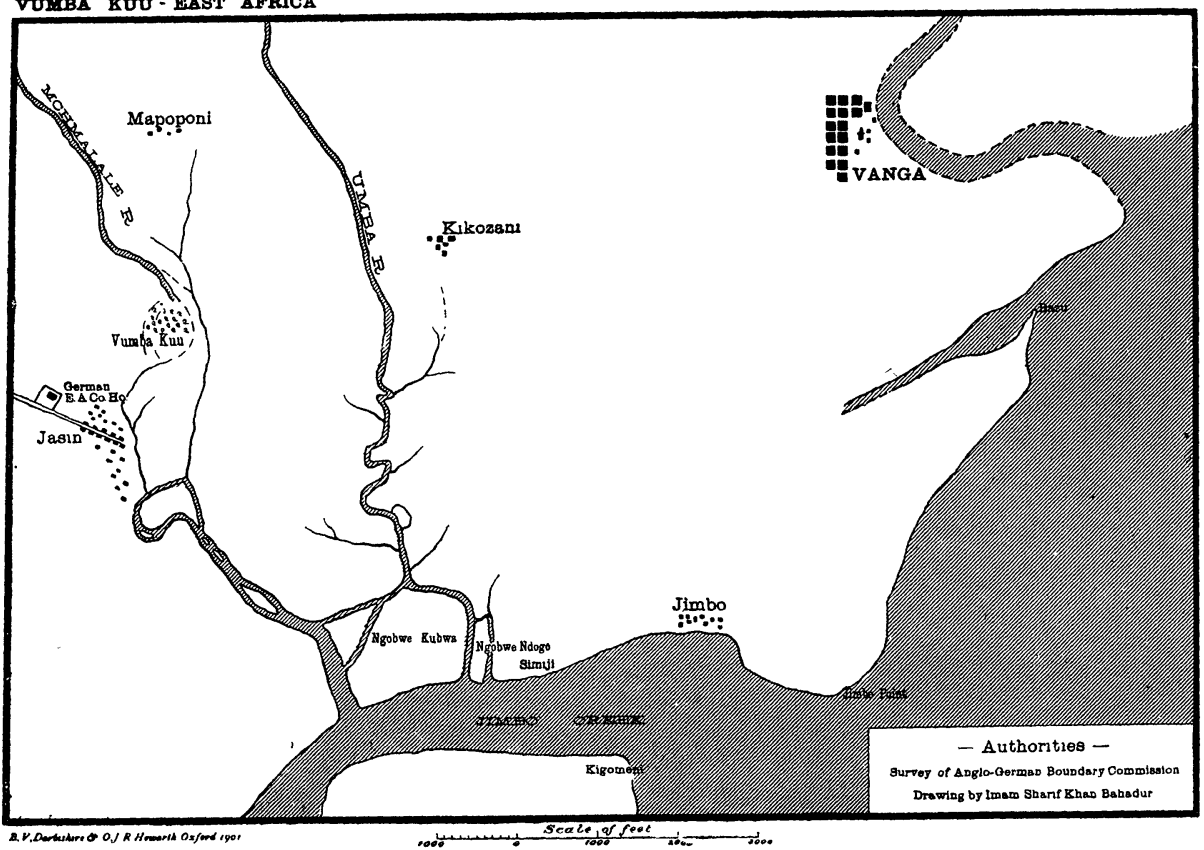




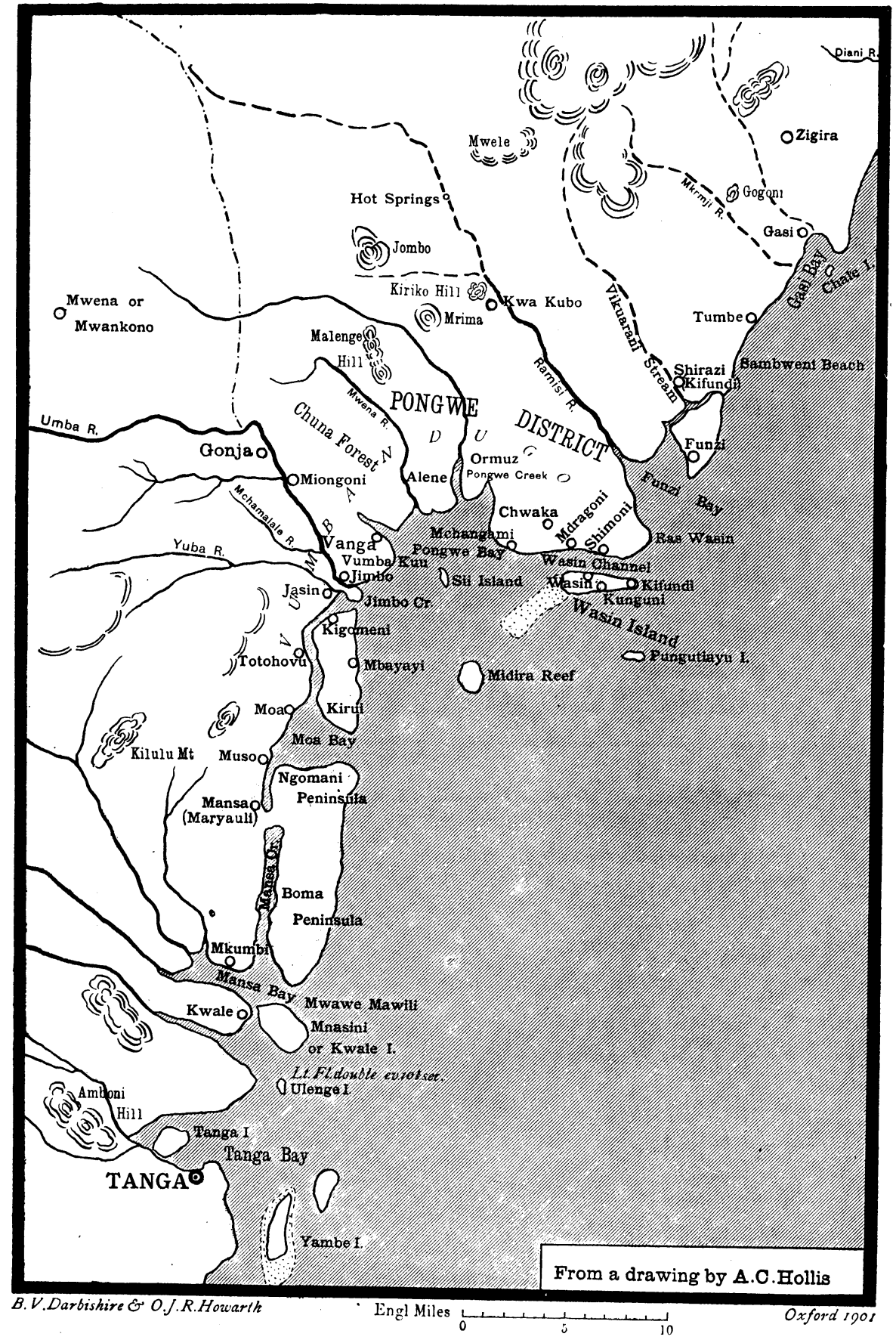

TIIE NEIGHBOURHOOD OF VUMB..

(The cential part of the upper map on Plate XXII: on a larger scale.) 


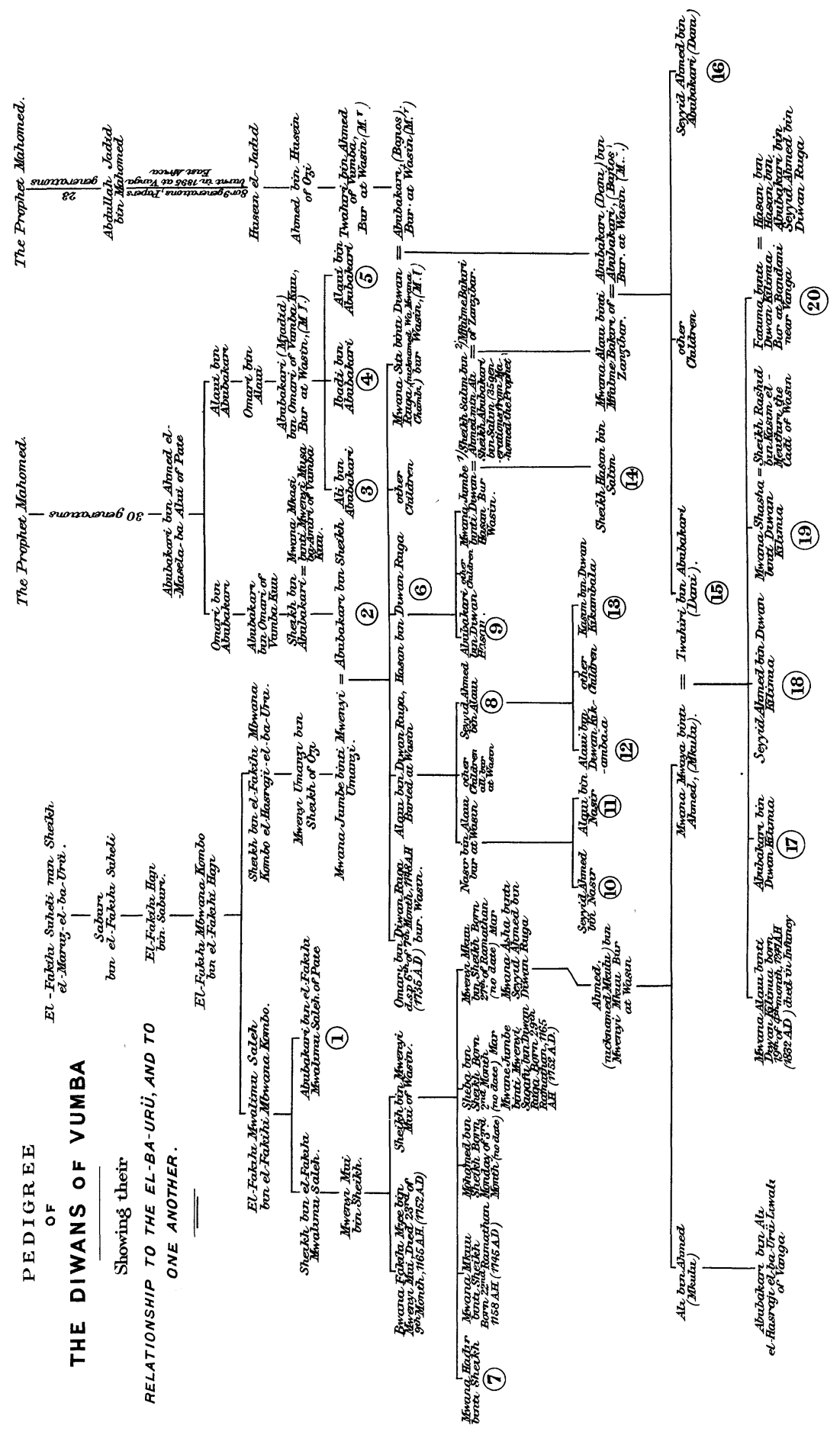

